\title{
THE APPLICATION OF AL-GHAZÂLI'S TASAWUF ETHIC TO ACTUALIZE GOOD GOVERNANCE IN INDONESIA
}

\author{
By: Agus Iswanto*
}

\section{Abstract}

This article tries to explore the possibilities of tasawuf ethic application to actualize Good Governance in Indonesia. The study focuses on some arguments why tasawuf and al-Ghazali are selected as the main discussion. The arguments are that Tasawuf is an Islamic tradition and al-Ghazali has capability for it in terms of his social lives. He proposed three concepts of thought concerning tasawuf ethics, that is, zuhd, teleological ethics, and ummahat al-fadhail. These concepts can be implemented in reforming good Indonesian government.

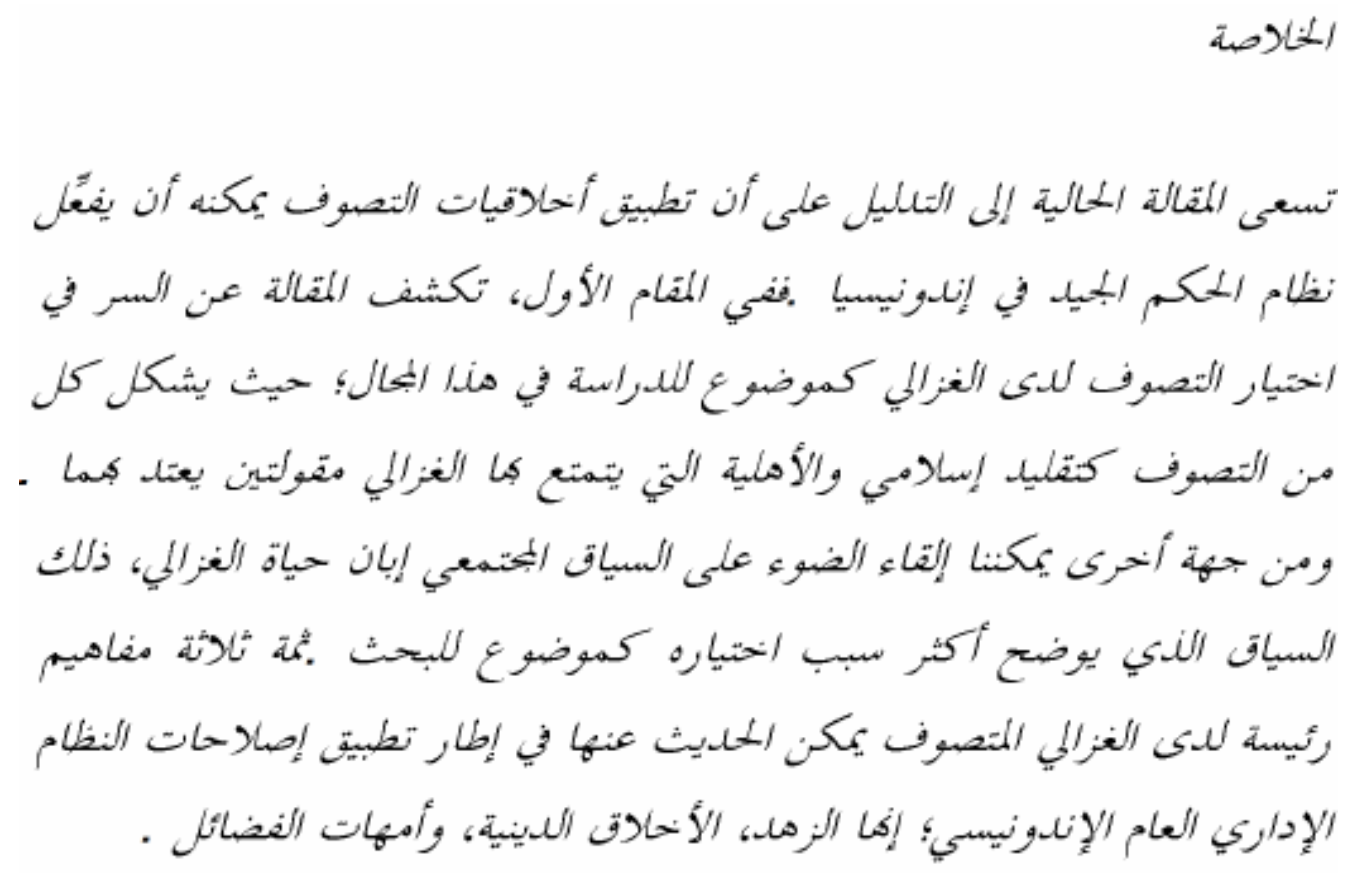

Keyword: Tasawuf, social sensitivity, Ilâhiyah consciousness, tasawuf tradition

* A student of Islamic Research at the Magister Studi Islam (MSI) of Indonesian Islamic University Yogyakarta. He is active in the institute for the study of pesantren and society (eLSipem) Yogyakarta. Email: freethinker_jogja@yahoo.co.id 


\section{A. Introduction}

Up to this day, disasters, the natural as well as the social ones, have been happening. National memory of the tsunami which wiped out part of Aceh is as fresh as the earth quake disaster that broken out part of Yogyakarta, the mud flooding tragedy of Lapindo and the spread of earth quake in many places of this beloved country of Indonesia. More disasters such as the avian influenza, the continued accident of airplanes, ships, as well as trains and cars are still threatening that seem to agree in saying of the "nature’s angry” to human beings, also flooding disasters give rise many people of the country to become apparently pessimistic with attempts that the government takes in immediate times. Still, in the mid of that calamity people are burdened by so many bad news and political attitudes of politicians which have no clear of it's working parameter.

The blurred standard of moral and the lacking commitment of it become worse to worse by the weak of law enforcement, and indeed law is often enforced discriminatively in many cases of corruption. There have been public officials people believed that they involved in corruption; unfortunately they still untouched by law, only some criminals have been punished oppressively. This state of being of course gives rise to the lose clear of border between lawful (halâl) and forbidden (harâm), right and wrong, good and bad and also weakened the government charisma and law. Moreover, such condition not only worsened bureaucratic culture but also depraves people attitudes in and towards good culture building.

Besides, the rumor of several members of the house of people representative (DPR) involved in bribe scandal every time they have a legal drafting agenda is currently on media circulation. ${ }^{1}$ Surely, this makes the image as well as the quality of politicians lacking warmth and generosity of spirit of morality. Thus, parameter or ethic within social life, bureaucracy and politics will be obscure and gray. With this reason, it is proper and reasonable to appear in the surface a critic that political parties

\footnotetext{
${ }^{1}$ Komarudin Hidayat (2007), “Menertawakan Kegetiran Hidup,” (Laughing at the bitter of life) in Kompas daily news paper, 21 April.
} 
have been failing to produce politicians with high quality of moral and integrity, and just the reverse is currently taking place that only the "opportunistic politicians" do exist.

People were angry and disappointing, and even rising-up currently when finally they found some religious public figures and university based intellectuals were also turning into and becoming political actors, then melted down that exhausted or degraded their moral commitment and their spirit of integrity.

So, who or what is deserved to be guilty? If such fundamental value as religion does not work to establish social sensitivity based on Ilâhiyah consciousness, then to whom or to what this country suggested to hope? Religion has been considered to be failed to transform the value of liberal-humanitarian, or amar ma'ruf in the language of al-Qur'an. A clear indicator of it is the spread of public figures, intellectuals, religious men (ulama) and Muslim leaders whom are melted down within the glamorous of power and wealthy while neglecting even forgetting the rights of people. ${ }^{2}$ Moreover, naively these leaders often outspokenly voiced on behalf of people or their public common interest. The theory was dead. This is perhaps the precise words to describe the "barren" of those intellectuals and religious men. Islam is simply laying on its formality. If such is the case, it is simply correct that religion is opium for society as Karl Marx (1818-1883) said, or "God has been retired" as Friedrich Nietzsce (1844-1900) proclaimed.

Yet, it is may be to much to pin the blame on religion because of religion (the religion from the sky, samawi, in particular) genuinely led human being to the way of rightness, the way to dzât Ilâhiyah which is transcendent. However, as soon as religion comes to the hand of human being it becomes culture, or even to be an

${ }^{2}$ Some phenomena can be observed. Currently, Islam --although too simplistic_-becomes a kind of commodity, goods to be sale. Everything changes and submits to the market interest and commodities. Islamic education also comes to the flow of market for the purpose of gaining benefit on behalf of quality. In fact, the quality hoped has never been attained. Thus, education only to produce people whom are ready to be employed or put differently education simply makes people capable of taking advantages opportunities for their own. 
ideology of the adherents. ${ }^{3}$ Here, the human's conception is very much influenced to any religious understanding. This understanding in turn will be actualized in every day life. As natural, such concept may be correct for the time in which it appeared, but it could be incorrect any longer for another time of current or future. The mismatch between concept and problem faced up in reality certainly will have a consequence for such concept to lost power to find the problem. Just the same as this, a concept of religion will not forever in accord to the real problem that is facing and appearing in current.

It is in this context that we need to establish new understanding, the one based on reality for problem solving. This new understanding, however, does not necessarily that we have to create the new one in all sense of the words. As we suggested knowing, Islam has the very rich of intellectual tradition, a kanzun makhâfi, which will never dry to be re-actualized, with critical assessment, in all times with the changes it has.

In what follows, this article tries to explore tasawuf tradition within Islam that is regarded in common as a "kanzun makhâfi." However, if tasawuf becomes only as beautiful as "hidden wealth", then it will give nothing of advantage and benefit. With this reason, the present article seeks to raise tasawuf tradition to the surface (and not to land it down from above) and to take advantages of it for the media of selftransformation towards the trasendent Ilâhiyah emanation within the context of Indonesian nation in which Muslims are the majority. In order to be focused the writer confines the study on alGhazâli, the most famous tasawuf figure, whereas aspect of tasawuf to be the point of study is ethic or moral tasawuf.

\section{B. Al-Ghazâli and Tasawuf}

Before discussing it further, the writer need to give reason why al-Ghazâli and Tasawuf becomes the subject of discussion. Furthermore, the question is why it is

\footnotetext{
${ }^{3}$ Machasin (2003), Islam Teologi Aplikatif (Islam Aplicative Theology), Yogyakarta: Pustaka Alif, p. 75.
} 
tasawuf that the priority is given to as an alternative for the crisis of this country, not to other Islamic traditions such as fiqh, kalam or philosophy of which does not less devoted its discourse in the study of Islam? What does the relationship of tasawuf with the current situation of Indonesian state and government?

The first question is, why tasawuf? Tasawuf is part of Islamic thought in addition to the science of Islamic theology (kalam), philosophy, jurisprudence (fiqh) or the philosophy of jurisprudence (ushul fiqh). ${ }^{4}$ The word "thought" here points out towards attempting to understand Islamic teachings.

The formula and the teachings of the prophet Muhammad which were modeled in his time have been changing and developing in line with the changing of social and culture in the reign of al-khulâfâ al-râsyidîn, the Ummayah and the Abbasiyah dynasty. This change and development are simply avoidable in as much as they are demand of the time, the geographic differences (which in due course of the time become the Hijaz school of thought, Kufah, Iraq and Persian) and the difference of social and historical background of the countries that comes to submit under Islam. ${ }^{5}$

Along with that development it came to appear Islamic sciences that have been influential at that time until nowadays. Such development can be seen at two levels. ${ }^{6}$ First, it comes to appear the science of exegesis (tafsir), the science of tradition (hadits), and the science of language. Second, it appears and then develops science of Islamic theology (kalam) along with its supporting figures such as Wasil ibn 'Ata', Abu Hasan al-Asy'ari, al-Maturidi. Their schools of thought are theology in nature such as Mu’tazilah, Asy’ariyah, and al-Maturidiyah. Discussions on the

\footnotetext{
${ }^{4}$ See for instance, in Nurcholis Madjid (1992), Islam Doktrin dan Peradaban (Islam Doctrine and Civilization), Jakarta: Paramadina. See also in M. Amin Abdullah (2006), Islamic Studies di Perguruan Tinggi: Pendekatan Integratif-Interkonektif, (Islamic Studies in University: An Approach of Integrative-Interconnection)Yogyakarta: Pustaka Pelajar, p. 302

${ }^{5}$ See Majid Fakhry (1987), Sejarah Filsafat Islam (History of Islamic Philosophy), trans. Mulyadi Kartanegara, Jakarta: Pustaka Jaya, p. 31-49

${ }^{6}$ M. Amin Abdullah (1996), “Tasawuf : Dimensi Batin Agama,” (Tasawuf The Religious Inner Dimension) in Studi Agama: Normativitas atau Historisitas, (Study of Religion: Normativity and Historicity) Yogyakarta: Pustaka Pelajar, p. 150-152.
} 
twenty attributes of Allah, the attribute of wajib, jaiz and mumkin al-wujûd were found in detail. After the contact had been made between Islam and Christian, Jew, Mineka and Greek, Muslim intellectuals untiringly reformulated Islamic teachings in line with and in order to answer questions of those teaching outside Islam. Several auxiliary sciences such as logic and philosophy were begin to be used to reformulate Islamic teaching that previously simple in order to defend and to make counter to those teaching outside Islam.

Still in the second level, it appears jurisprudence (the science fiqh) along with its supporting figure such as Syafi'i, Hanbali, Maliki, and Hanafi. Within this science, tents or even hundreds of books have been produced by Muslim intellectuals. The subject of five Islamic pillars for example, which was previously very simple have been widened and classified into many chapters of ablution (wudhu), ablution with dust (tayammum), taking a bath, performing praying, pilgrim, giving alms and the social matters completely with all arguments taken from the holy al-Qur'an and tradition of the prophet supplemented with the logic arranged by each leader of the scholl of thought (madzhab). However, because the discussion and the way of thinking it takes too much focused on making every acts in line with the rules of jurisprudence within any school of thought the it religious spirit become relies heavily on formalistic and legalistic side only.

Disappointing with such religious feature which is too formalistic and extrinsic in nature proposed by theology and jurisprudence, then appear tasawuf which is more to appreciate the inside aspect (bathiniyah) or the substance of being religious. 
Apart from the debate on the origins of the Schools of thought in Sufism, ${ }^{7}$ tasawuf and Sufism have been able to catch the biggest part of Muslims attention. In history, indeed, we can see that Islam was introduced to Indonesia through religious proselytizing conducted by sufi leaders. ${ }^{8}$ The spreading of tarikat movements, the orthodox as well as the heterodox ones were evidence that tasawuf movement had been able to call attention most people. Sufi leaders did not satisfied with religious understanding which is intellectual in nature intrinsic with theologians and philosophers, and religious understanding which is too much legalistic as well as formalistic.

Several terms in al-Qur'an which are full of inside religious spirit (bathiniyah) have been compiled by sufi figures such as Taubât, Syukr, Shabr, Tawakal, Ridhâ, Ikhlâs, Wara', Qanâ'ah, Raja', Hubb, and Khauf. ${ }^{9}$ These terms in turn become indication for someone to be able to become a sufi, then one is suggested to be capable of being close to Allah (Taqârub ila Allah).

Unfortunately, tasawuf has breaked off for long time on individual attitudes without giving any ideas of the possible implication of such attitudes as zuhd, 'uzlah, or qanâ'ah to social problems. Furthermore, tasawuf, unexpectedly had been pit in to unhealthy rivalty between groups of tarikat for gaining adherents. If such is the case, tasawuf then does not differ from the two other modes of thinking namely Islam theology (kalam) and Islamic jurisprudence (fiqh), whereas it is like the hidden wealth which always to be hunted or is like magnet hidden under the surface but has

${ }^{7}$ On the origins of the schools of thought in Sufism, Harun Nasution proposes at least five theories. (1) The influence of Christianity on the understanding to avoid the world and isolation by living in monasteries (2) the influence of Pythagoras' mystic philosophy on the outlook that the soul of human being is eternal whereas living in the world is strange (3) the influence of Plutonius' philosophy of emanation on the reason that the existential being is emanation from God. (4) the influence from the teachings of Budha on Nirwayana, and (5) the influence of Hinduism for avoiding the world ness and come to close with God in order to unity the Atman and Brahmana. See Harun Nasution (1999), Falsafah dan Mistisisme dalam Islam, (Philosophy and Misticism within Islam) Jakarta: Bulan Bintang, p. 55-56.

${ }^{8}$ See for instance the research by Azyumardi Azra (1999), Jaringan Ulama Timur Tengah dan Kepulauan Nusantara Abad XVII dan XVIII, (The Network of Middle East Ulama and Archipelago of the XVII and XVIII centuries), Bandung: Mizan.

${ }^{9}$ Harun Nasution (1999), op.cit., p. 62-67. 
extraordinary power. This power or potency may be used for everything. Within modern style of life which is materialistic for instance tasawuf can be developed towards establishing individual as well as social life to be meaningful. To this end, the writer proposes to re-actualize tasawuf and to make it an alternative to solve our national crisis based on its basic characteristic namely emphasizing the inside aspect of religious with the concept Ihsân in everyday practices of social and religious life. ${ }^{10}$

The second question is why al-Ghazâli ${ }^{11}$ ? The reason for this is really very much subjective. Nevertheles, the subjectivity of choosing him by no mean without good reasoning. At least there are two reasoning can be suggested in relation to the main subject this article wants to deals with.

First, al-Ghazâli himself as a Hujjat al-Islâm. This leads him to be a central figure to which Muslims all over the world referred in many religious practices. The fact also says that Indonesian Muslims also know al-Ghazali even make him a figure to be followed. This fact remains true for the biggest part of Indonesian Muslim are of Asy'ariah adherents in theology that is well known by Ahl al-Sunnah wa alJamâ'ah or Sunni -even though there still disputation on and struggle to gain meaning of being Sunni in Muslims groups in Indonesia. ${ }^{12}$

Al-Gazali's charisma as a religious figure is as strong as magnet that attracted very much people. This certainly will be the advantage power and positive potency if only to be done re-construction and re-formulation of its tasawuf for establishing social order of Indonesia’s Muslim majority.

10 This perhaps have been practicing by Islamic organization such as Muhammadiyah that translated tasawuf into social ethics articulated in developing society such, constructing schools building, hospitals houses for orphan children and other social purposes. The same is Nahdlatul Ulama (NU), which strongly accommodated sufi teachings, actualized tasawuf into several social institutions. M Amin Abdullah (1996), op.cit., p. 156.

${ }^{11}$ His full name is Abu Hamid Muhammad bin Muhammad bin Ahmad al-Ghazali. He was born in village Ghuzala the region of Thus, one city in Khurasan, Persia in 450 H/1085 CE. Abdul Hadi Abu Raidah (1938), Tarîkh al-Falsafah al-Islâm (History of Islamic Philosophy) Kairo: Lajnah Ta'lif wa al-Tansyir, p. 199.

12 See Said Aqil Siroj (2006), Tasawuf Sebagai Kritik Sosial: Mengedepankan Islam sebagai Inspirasi, bukan Aspirasi (Tasawuf as Social Critic: Islam as Inspiration, not Aspiration), Bandung: Mizan. 
Secondly, al-Ghazali as the subject of this discussion has to do with his social life which is relatively identical to the situation of social life that Indonesia and Muslim communities have. Here, to contextualize the social and historical condition of al-Ghazali into the situation of Indonesia's current is done by using hermeneutical approaches.

Before al-Ghazali had been born, societies had experienced decline and backwardness. In the field of social and political life, the Abbasiyah dynasty, a symbol of Islamic unity, had been so weak. This weakness according to Montgomery Watt, was caused by three condition: (1) the weakness of control system after widening territorial dynasty (2) the increasing dependency to paid armies (3) inefficiency of the financial system management. ${ }^{13}$ In other fields, such as intellectual, moral and religion in general also experienced backwardness and weakness. Hence, the central Abasiyah dynasty became weak and weak whereas its regional part became strong, such as the dominant influence of Buwaihi dynasty over Baghdad. Abasiyah then collapsed by the Hulagu Khan. The Saljuk dynasty that came to power after the Buwaihi dynasty in the mid of XI century also fail to restore the political power of Islam for the latter could only hold the power for about thirty years. ${ }^{14}$

At the time that the Saljuk dynasty had been weakened politically along with the collapse of national stability al-Ghazali came to life. Hence, in his life time the situation of Muslims societies were experiencing backwardness almost in all aspect of life. In the field of education and psychology, they experienced intellectual malaise, spiritual and moral. The disorientation was dominating the life of people that glamorous life style defeated the religious one instead. Religion that needs practices was often to be used for popularity, to gain power and position within government. Within the field of culture and science, although advantages had been achieved, this was not in line with the spiritual, moral and religious progress. The fact remained that

\footnotetext{
${ }^{13}$ Watt, W Montgomery (1990), Kejayaan Islam, Yogyakarta: Tiara Wacana, p. 165-166.

${ }^{14}$ Ibid., p. 248-249
} 
people seemed to seek only worldly benefit in developing science and culture while neglecting the day after life. This was realized by al-Ghazâli in his book al-Munqidz min al-Dhalâl. ${ }^{15}$ The field of thought was not free from problem also, namely the polarization and the pluralism of understanding which come about to make truth claim of their own.

Coming to deals with Muslims societies full of social and political fragmentation and shadowed by uncontrolled liberal thoughts along with the spreads of parochial understanding, the weakened attitude of tolerance between their co believers, al-Ghazali came his courageous decided to undergo the way of sufi. He went through it as the foundation of his theological underpinning. This attitude recorded in his book Ihyâ 'Ulûm al-Dîn. That is why his book is full of teachings on moral and spiritual contents as an attempt to defend the right outlook of reality through going back to the way of Allah the almighty.

Slight description of the real situation of social and cultural context that alGhazali faced in his time gives us clear information why he finally decided to have tasawuf an alternative for the problem of social and religious that Muslims people at that time experiencing. This situation is not far different with the situation of current Indonesian actually. So, does it possible to have al-Ghazali's tasawuf a way to solve such problem? It is by no mean to simplify the problem if the writer answers positively. The argument we can proposed is that if the inner soul has been dumb anymore, so what else we can proud of as a human being? The problem of inner soul is definitely of inner spiritual (batiniah) matter, and this is obviously the problem of tasawuf. As we suggested to know the most talked subject in tasawuf is dealing with moral or ethic, individual as well as social. ${ }^{16}$

\section{Al-Ghazâli’s Tasawuf Ethic}

${ }^{15}$ Al-Ghazali (tt), Al-Munqidz min al-Dhalâl, Beirut: Al-Sya'biyah, p. 71.

${ }^{16}$ M. Amin Syukur, dan Masyharuddin (2002), Intelektualisme Tasawuf: Studi Intelektualisme Tasawuf al-Ghazali, ( Intellectualism of Tasawuf: A Study of Al-Ghazali’s Intellectualism Tasawuf) Yogyakarta: Pustaka Pelajar, p. 183. 
The writer tends to use the term ethic than akhlak, even though the latter is well known more among Muslims. Ethic is well known in philosophy tradition ${ }^{17}$ rather than in tasawuf. Within Islamic intellectual treasury in general or within tasawuf in particular ethic is often or well known by the term akhlak. Ethic also is constituted equally as moral. The two terms apparently points out to the same meaning that is the living values or norms within a community. However, they differ to each other in the origins of its words, if ethic originated from the Greek, moral is taken from the language of Latin. ${ }^{18}$

In contrast, akhlak is more intended to be a normative and binding ready- to use-product that has to apply by a Muslim in his/her daily Akhlak is a set of religious values that have to be actualized in daily life with no need of critical analysis and question. ${ }^{19}$ Ethic always achieved with reflection process, whether by using logical reasoning ('aqliyah) or intuitive. ${ }^{20}$

In line with the basic ideas of tasawuf that emphasizes esoteric aspect and substance in every conduct, the ethic of tasawuf is not merely about ethic in a narrow sense of moral that stresses on exoteric aspect but it goes beyond the exoteric to achieve the deepest sense of every conduct and behavior. If tasawuf means a reflection about good and bad which brings forth moral of conduct and behavior, its consideration of good and bad is based on enlightened heart. The ethic of tasawuf does not care about material aspect because for a sufi material is not the aim and also not important. The ultimate goal of every conduct for a sufi is to come to close to Alloh (taqârub ila Allâh) or even kasyf, being in adjacent with Allah the almighty.

${ }^{17}$ M. Amin Abdullah (2004), Falsafah Kalam di Era Postmodernisme, (The Philosophy of Kalam in the Era of Postmodernism) Yogyakarta: Pustaka Pelajar, p. 146.

${ }^{18}$ K. Bertens (2001), Etika, (Ethic) Jakarta: Gramedia Pustaka Utama, p. 4-7.

${ }^{19}$ M Amin Abdullah (2004), Falsafah Kalam (The Philosophy of Kalam )..., p. 147.

${ }^{20}$ Within Western epystemology, intuition has not been given position as a method for achieving knowledge whereas within Islamic epistemology, in addition to the empirical and logical, the intuitive knowledge is also recognized as valid method to achieve genuine knowledge (ma'rifât). See

Mulyadhi Kartanegara (2003), Menyibak Tirai Kejahilan: Pengantar Epistemologi Islam, (Scrutinizing Screen of Blindness: AN Introduction to Islamic Epistemology) (Bandung: Mizan, p. 1829. 
As a Sufi, al-Ghazâli does have a theory of ethic as a part of his tasawuf discipline. Some experts comes to consider al-Ghazâli as a Sufi figure, some other also goes to classify him as a prominent figure of philosophy. This is understandable actually, because from the books he wrote all indicates his interest on both tasawuf as well as philosophy. By considering his books Maqâshid al-Falâsifah or Tahâfut alFalâsifah, or through his Mi'yâr al'Ilm, one would consider him as a true philosopher. But one might also comes to conclude him as a real Sufi or a true mystic simply by looking at his master piece works such as Ihyâ al-Ulûm al-Dîn, or Kitab al-Arbâ'in dan al-Munqidz min al-Dhalâl. ${ }^{21}$ It is suggested that the two approaches are combined to have an integral view of al-Ghazâli and his thoughts. Based on this reason the study of al-Ghazâli's tasawuf ethic would be conducted comprehensively only if the two ways of his thoughts were taken into account

In this article the writer uses two terms that have been very famous, namely moral tasawuf (tasawuf akhlâki) ${ }^{22}$ and philosophical tasawuf (tasawuf falsafi). ${ }^{23}$ The usage of these two terms, however, will be in not rigid way in order to understand easier the characteristic of al-Ghazâli's tasawuf ethic thought that in turn can be actualized in everyday life. In addition to the aforementioned terms we find another one in this context namely tasawuf 'amâli. ${ }^{24}$ Here, the Tasawuf akhlâki dan tasawuf falsafi is meant by the writer as a process of reflection on ethic as good and bad. These two then generate tasawuf 'amâli (practice) that is a reflection produced in a conduct. The Tasawuf akhlâki is based more on religious teachings whereas tasawuf falsafi is based more on reasoning which is influenced more by philosophical thoughts.

\footnotetext{
${ }^{21}$ M. Amin Abdullah (1996), Studi Agama (Study of Religion)..., p. 270.

22 Moral tasawuf (Tasawuf akhlâki) is tasawuf teaching that deals with the soul's comprehensiveness and purity formulated in mental attitude arrangement and the rigid behavior disciplinary for achieving optimal happiness. M. Amin Syukur (2002), op.cit., p. 45

${ }^{23}$ Philosophical tasawuf means tasawuf teaching which combines the intuitive and rational vision. Ibid., p. 51.

${ }^{24}$ Tasawuf Amali namely, the tasawuf which deals with how to come to close to Allah. This kind of tasawuf is often meant as the tarikat movement Ibid., p. 50.
} 
In the perspective of tasawuf akhlâki, al-Ghazâli's tasawuf ethic can be seen in his concept of zuhhd. In his book al-Arbâ'in, ${ }^{25}$ al-Ghazâli defines zuhd as the turning of an individual from worldly concern notwithstanding he or she is able to attain it. Al-Ghazâli divides the zuhd level of motivation to three stages:

1. Zuhd motivated by the fearful of hell. The Zuhd of this level is one for those of cowards.

2. Zuhd motivated to have life pleasant in the hereafter. This level of Zuhd is for those of having hopes, which their contact to Allah is band by hope and love not by one of fearful

3. Zuhd motivated by the will to leave out from paying attention to everything except Allah in order to have the soul clean and pure and to consider not important whatever except Allah. This level of Zuhd is for 'ârifîn, those who have attained the degree of ma'rifât. ${ }^{26}$

According to al-Ghazâli, in advance to ma'rifât one has to experience mahabbah. Through mahabbah will gives rise ma'rifât. For strengthening ma'rifât on Allah in one's heart, he/she needs to have self cleaning from worldly business. ${ }^{27}$

In the perspective of "philosophical tasawuf” al-Ghazâli's thoughts of tasawuf ethic can be seen from the law of causality or motive and consequence. ${ }^{28}$ This idea of causality generated the characteristic thought of ethic inclined to be teleological. ${ }^{29}$ This thought of ethic actually that brought about the theory of teleological ethic. This

\footnotetext{
${ }^{25}$ As quoted by M. Amin Abdulah (1996), op.cit., p. 278.

${ }^{26}$ Ibid., p. 278-279.

${ }^{27}$ Ibid., p. 278.

${ }^{28}$ Ibid., p. 271.

${ }^{29}$ Teleology is derived from the word telos (aim) and logos (knowledge). In the study of

teleology is knowledge that serves as an argument on the existence of God saying that every creature bears it's own aim in its evolution. However, the world itself can not determine this aim, for only thing beyond the world is capable to control it namely God. See Harun Nasution (1979), Filsafat Agama, Jakarta: Bulan Bintang, p. 60-62.
} philosophy 
ethic constitutes a branch of normative ethic stating that good or bad of any conducts are determined, from the view point of ethic, by its aim and objective. ${ }^{30}$

This thought is inclined to the Aristotle's thought which then followed by Muslims philosopher such as Avicenna, al-Farabi and Ibnu Miskawih who considers the value of good or bad of any conduct based on its consequence whether to increase or to hinder happiness (al-sa'âdah). ${ }^{31}$

In Ihyâ al-Ulûmuddîn, this theory of teleological ethic is very clearly proposed by al-Ghazâli. According to him, positive objective of human being is to achieve happiness in the hereafter. For this reason, human conduct is considered good if such conduct generated positive influence on and directed the soul toward objective of the human conduct and the same is the reverse. ${ }^{32}$ Hence, the measurement on good or bad of conduct can be differentiated for there are influences resulted to the soul of the actor whether to come to close to God or to leave Him away. ${ }^{33}$

Indeed this theory of ethic can bee converged with the above concept of zuhd. A person whose live objective is only Allah, consequently the world of materialism is none of his/her aim to achieve. This is parallel with the concept of zuhd at the third level which is the zuhd for those of 'arifin, who cleaned their self from everything except Allah. Except Allah, for a zâhid (an individual who practices zuhhd) all things are not the objective for achieving the hereafter happiness. Because not gives the hereafter happiness they have to be leave out at all.

Another al-Ghazâli’s thought of ethic within the context of the philosophical tasawuf is the outlook on the sources of lofty (ummahât al-fadhâil). Lofty here means the well functioning condition of all energy that an individual has in accord with the

\footnotetext{
${ }^{30}$ Bertens also calls this ethic as the ethic system of consequential, holding the view that good or bad of conduct is considered on its consequence, its result; all are oriented towards the objective of conduct.

K Bertens, op.cit., p. 254 .

${ }^{31}$ Abu al-Quasem (1988), Etika Al-Ghazali, (Ethic of Al-Ghazali) trans. Muhyiddin, Bandung: Pustaka, p. 14.

32 Al-Ghazâli (tt), Ihyâ al-Ulûmuddîn, jilid IV, Beirut: Dar al-Filler, p. 138.

33 Ibid., jilid II, p. 9-11.
} 
guidance to become a lofty person. ${ }^{34}$ Out of functioning of this energy will cause badness (al-razâil). ${ }^{35}$ In his Mizân al-’Amal, al-Ghazâli demans balances (al-'adl) between all this energy. Al-Ghazâli states the highest four of lofty, namely: al-hikmah as the intellect lofty. al-syajâ'ah as the lofty of al-ghadb (the energy of anger), al'iffah as the lofty of al-syahwah (desire energy), dan al'adalah as the lofty of or the factor for making balance. Al-'adl is balance form two ways, namely from the positioning of each energy in between of two bad nesses and from the positioning of intellect as a control tool. ${ }^{36}$ For example $a l$-ghadb and al-syahwah are two inherent tendencies energy of impetus (al-ba'its) or will (al-irâdah). Al-ghadb will give rise brevity to do against everything that mislays the self. And with al-syahwah a person will attempt to have for it self something that is advance. Without higher energy alghadb will give rise wildness whereas al-syahwah will cause greedy. For this reason, it is a need to have balance factor ( $a l$ - $\left.^{\circ} a d l\right)$, that is intellectIt will catch out al-hikmah which functions to put everything properly. ${ }^{37}$

This view of balance (al-tawassut) can be traced back to Aristotle. But such a view had been founded in advance by Muslim philosopher before prior to al-Ghazali, such as Avicenna, al-Farabi and Ibnu Miskawih. ${ }^{38}$

\section{E. Closing: Theoretical Implication}

The substance of tasawuf way of life is modesty. Tasawuf calls human being to leave off so that human will fully free and not to submit to anything except Allah the merciful. Tasawuf calls to equality, to help each other and to make close brotherhood. Tasawuf creates and builds a perfect individual. ${ }^{39}$

\footnotetext{
${ }^{34}$ Murad Wahbah (1971), Al-Mu'jam al-Falsafi, Kairo: al-Tsaqofah al-Jadidah, p. 161.

${ }^{35}$ Ibid., p.103.

${ }^{36}$ Al-Ghazali (1964), Mîzân al-Amal, Mesir: Dar al-Ma’arif, p. 272.

${ }^{37}$ M. Amin Syukur (2002), op.cit., p. 186.

${ }^{38}$ Muhammad Yusuf Musa (1963), Falsafah al-Akhlâk fi al-Islâm, Kairo: Muassah al-Khatji, p.

${ }^{39}$ Lihat Muhammad Zaki Mubarak (2002), Tasawuf Salafi: Menyucikan Tasawuf dari NodaNoda, (Tasawuf Salafi: Cleaning Tasawuf from disgraces) Jakarta: Hikmah, p. 16.
} 203, 205. 
The concept of zuhd, the idea of hereafter happiness and the life balance concludes in the attitude of life modesty or simplicity. The modesty will get rid off greedy. This attitude is caused by the dominance of al-syahwah energy. All must be controlled for having pleasure although by using bad ways and mislaying others. Corruption among other is caused by al-syahwah domination. The culture of corruption, collusion and nepotism along with none transparence in the state governance is clearly an indication of the increased dominance of al-syahwah. Besides, after al-syahwah, al-ghadb is also strengthening such as unhealthy rivalries, series of violence and spreading slanders. All have been done just for securing desire produced by al-syahwah energy.

When al-Ghazali decided to have tasawuf as his way of life with the attitude of zuhd, this was the situation forced him to so, because, for him the worldy pleasure will not give the hereafter happiness. According to writer, not only in the hereafter, but also in this world human will suffer from loose. Backwardness, poorness and stupidity are or worldly misfortune caused by loving too much materialism. Too much their love is that everything needs to be controlled. Intellectual and heart are no more functioning. For this reason, there no balance anymore. This unbalance in turn will bear on the chaos situation with no certain direction and continuing crisis.

Zuhd for current time and in the context of good governance can bee actualized by enforcement of cultural transparence, fairness, accountability, responsibility, efficiency, and the effective and strategic vision. All will possibly be done if al-Syahwah and al-Ghadb energy can be minimized or balanced by heart and intellectual. As a concept, the ethic of tasawuf has not yet been a "ready to use rule", however, the spirit of this ethic is need of enforcement in every planning of healthy state governance. Zuhd -in its new sense- has to be well known or even need to be studied to those who are going to lead this country. Moreover, conglomerates, peasants, employees and those of ulama have to be given awareness of this concept of Zuhd. Indeed, it is better if the Zuhd in its new sense be included into the curriculum of civil education. 


\section{BIBLIOGRAPHY}

Abdul Hadi Abu Raidah (1938), Tarîkh al-Falsafah al-Islâm, Kairo: Lajnah Ta'lif wa al-Tansyir.

Abu al-Quasem (1988), Etika Al-Ghazali, translated by Muhyiddin, Bandung: Pustaka

Azyumardi Azra (1999), Jaringan Ulama Timur Tengah dan Kepulauan Nusantara Abad XVII dan XVIII, Bandung: Mizan

Bakker, Anton dan Achmad Charis Zubair (1990), Metodologi Penelitian Filsafat, Yogyakarta: Kanisius

Bertens, K (2001), Etika, Jakarta: Gramedia Pustaka Utama

Al-Ghazali, Abu Hamid Muhammad ibn Muhammad ibn Muhammad (tt), Ihyâ alUlûmuddîn, jilid IV, Beirut: Dar al-Fikr

--------- (1328), Kitâb Al-Arba'în fî Ushûl al-Dîn, Mesir: Kurdistan al-’Ilmiyah

----------, Al-Munqidz min al-Dhalâl, Beirut: Al-Sya’biyah

--------- (1964), Mizân al-Amâl, Mesir: Dâr al-Ma’ârif

Harun Nasution (1979), Filsafat Agama, Jakarta: Bulan Bintang

Harun Nasution (1999), Falsafah dan Mistisisme dalam Islam, Jakarta: Bulan Bintang

Lorens Bagus (2000), Kamus Filsafat, Jakarta: PT. Gramedia Pustaka Utama

Komaruddin Hidayat (2007), “Menertawakan Kegetiran Hidup” in Kompas, 21 April 2007, Jakarta

M. Amin Abdullah (1996), “Tasawuf: Dimensi Batin Agama,” in Studi Agama: Normativitas atau Historisitas, Yogyakarta: Pustaka Pelajar

--------- (2002), Antara al-Ghazali dan Kant: Filsafat Etika Islam, Bandung: Mizan

---------- (2004), Falsafah Kalam di Era Postmodernisme, Yogyakarta: Pustaka Pelajar

(2006), Islamic Studies di Perguruan Tinggi: Pendekatan IntegratifInterkonektif, Yogyakarta: Pustaka Pelajar

M. Amin Syukur (2002), Intelektualisme Tasawuf: Studi Intelektualisme Tasawuf alGhazali, Yogyakarta: Pustaka Pelajar

Machasin (2003), Islam Teologi Aplikatif, Yogyakarta: Pustaka Alif

Majid Fakhry (1987), Sejarah Filsafat Islam, translated by Mulyadi Kartanegara from A History of Islamic Philosophy, Jakarta: Pustaka Jaya 
Muhammad Yusuf Musa (1963), Falsafah al-Akhlâk fi al-Islâm, Cairo: Muassasah alKhatji

Muhammad Zaki Mubarak (2002), Tasawuf Salafi: Menyucikan Tasawuf dari NodaNoda, Jakarta: Hikmah

Mulyadhi Kartanegara (2003), Menyibak Tirai Kejahilan: Pengantar Epistemologi Islam, Bandung: Mizan

Murad Wahbah (1971), al-Mu'jam al-Falsafi, Kairo: al-Tsaqofah al-Jadidah

Nurcholis Madjid (1992), Islam Doktrin dan Peradaban, Jakarta: Paramadina

Said Aqil Siroj (2006), Tasawuf Sebagai Kritik Sosial: Mengedepankan Islam Sebagai Inspirasi, Bukan Aspirasi, Bandung: Mizan

Watt, W Montgomery (1990), Kejayaan Islam, Yogyakarta: Tiara Wacana 